\title{
THE WORK OF DISASTER: Building Back Otherwise in Post-Earthquake Nepal
}

\author{
AIDAN SEALE-FELDMAN \\ University of Virginia \\ (D) https://orcid.org/0000-0003-2209-1487
}

Prem is listening to a small, handheld radio, his cigarette glowing in the darkness. Through the sounds of the night, the crackling voice of a man can be made out as he describes the concept of depression and the benefits of counseling and sharing, spoken in Nepali Bhasa peppered with these English terms. The voice explains that there is medicine for depression, but that it is better to begin with counseling. That people have many kinds of tension, but when you share your tension, when you no longer make your tension hide, you can improve on your own; that your man, your heart-mind, will become light. "This is the meaning of counseling: listening to people's problems," says the voice. A caller calls into the show, his voice is barely audible. He says that he feels as if the earth won't stop shaking. Prem switches off the radio.

Audio 1. Prem's Radio. While getting ready to sleep outside together we listen to a voice explain the symptoms of "depression" on a call-in FM radio show-an early indication of the postdisaster expansion of psychiatric discourse in Nepal. Recording by Aidan Seale-Feldman. of journal content for the above purposes should credit the author and original source. Use, reproduction, or distribution of journal content for commercial purposes requires additional permissions from the American Anthropological Association; please contact permissions@americananthro.org.DOI:10.14506/ca35.2.07 
From 2014 to 2016, I conducted fieldwork on global mental health and psychosocial transformations in Nepal, living and working among small farming communities, nongovernmental organizations (NGOs) for mental health and counseling, psychiatrists, psychosocial counselors, and development and humanitarian aid workers. As part of this work I had been exploring the conceptualization and contestation of affliction between psychiatric and indigenous worlds against the backdrop of the emergence of global mental health in Nepal (Seale-Feldman 2019, 2020). In 2015, eight months into my fieldwork, a 7.8 magnitude earthquake and a 7.3 magnitude aftershock struck Nepal, claiming more than 9,000 lives, generating a massive influx of humanitarian programs for mental health and counseling, and rapidly changing the therapeutic landscape. The disaster radically reconfigured the field: as the earth beneath Kathmandu was jolted ten feet to the south, it ripped open both the material landscape and my conceptualization of the field.

At the time of the earthquake I was conducting research in a rural hill district in eastern Nepal. Although the village escaped the total decimation of both earthquake and aftershock, we felt, heard, and feared the shaking. For the month following April 25, we (my adoptive family, of which Prem was part, and I) slept outside, together, in mangers and on porches, avoiding the inside of the threestory mud house. We kept the solar-power radio on at all times, using it as our main source of information. At night the family listened to Radio Nepal as we lay side by side under blankets in the open air. In every day that followed, a psychosocial program called Speaking Listening (bhandai sundai, a post-earthquake program funded by UNICEF) was broadcast on the radio. On the broadcast people talked about manasik rog, mental illness, and explained the concept of depression, listing its symptoms. Callers phoned in to share their stories, and received advice from a psychosocial counselor or psychiatrist live. ${ }^{1}$ The appearance of the radio program and the new presence of mental health discourse in this region indicated that the disaster and its humanitarian response could have implications for this once minor field.

What does disaster generate? To think through the unfolding of disaster, I read theories of event and crisis through a critical phenomenological lens to trace what I call the work of disaster. The work of disaster encompasses what is generated through the event and what is destroyed, what is accomplished through narratives of crisis and what is foreclosed, and the processes by which affliction is made visible or rendered invisible. ${ }^{2}$ Such work is done by the earth itself by destroying worlds and creating possibilities for new life, and by humans for whom the disaster and its management differentially reveal forms of suffering and generate opportuni- 
ties for transformation. An earthquake is a sudden release of energy. When stress builds up along a fault line, eventually it will rupture, generating seismic waves that travel through the earth's layers into the lithosphere. The seismic event and the shifting of tectonic plates occurs without respect to the network of lives above it, yet the demands the event makes, the ethical response it garners, and the forms of work it requires reflect the particular historical, social, and political context in which it occurs.

Disaster studies have long pointed out the power of catastrophes to reveal and disclose hidden truths about society and act as catalysts for transformation (Kreps 1995; Oliver-Smith 1996; Hoffman 1999; Oliver-Smith and Hoffman 2002). Yet as Roberto E. Barrios $(2017,157)$ has argued, "rather than be revelatory crises, disasters are perhaps better described as contested arenas where hegemonic visions of societal advancement are challenged by the voices and experiences of those most impacted by catastrophes." Disasters do work not only by destroying but also by generating new possibilities for becoming and natality (Arendt 1998; Solnit 2009). ${ }^{3}$ The ontological destruction of worlds requires human work to rebuild those worlds, often creating new forms of knowledge practices and experimentation for the management of life (Fortun 2001; Petryna 2002; Bond 2013; Tironi 2014). Yet the particular form the work of disaster takes, and the new worlds it may generate, are determined by a priori assumptions of what such worlds should be. Unlike other approaches to disaster, critical phenomenology helps us attend closely to the "politics of the a priori" (Zigon 2018, 3) that delineate not only what is revealed and for whom (Barrios 2017) but also the competing visions of world-building set into motion by the work of disaster.

I begin with the work of disaster as a frame through which to trace the emergence of a crisis in the aftermath: its strategic uses, ethical demands, and unexpected consequences. A phenomenological perspective focused on the objectification of crisis makes strange the unquestioned necessity of humanitarian psychosocial intervention that appears and justifies itself according to its own practices, speech acts, and discourses of truth (Roitman 2013). In the realm of mental health governance, I describe how the work of disaster generated two interconnected consequences through the biopolitics of humanitarian intervention. People who received psychosocial counseling after the disaster were often treated for chronic problems that had become momentarily visible through the event and the ethical demand it necessitated. At the same time, humanitarian and development agencies were well aware of the logics of crisis and strategically used the disaster as an opportunity to increase mental health governance in Nepal under the rubric of 
"building back better." In this article I follow the emergence of a mental health crisis in Nepal to identify how predetermined frames and genres of crisis, suffering, and "the better" were engaged as part of the humanitarian response. I argue that a priori frames of crisis and its required interventions delineate and foreclose imagined possibilities both for care and for building the world back otherwise.

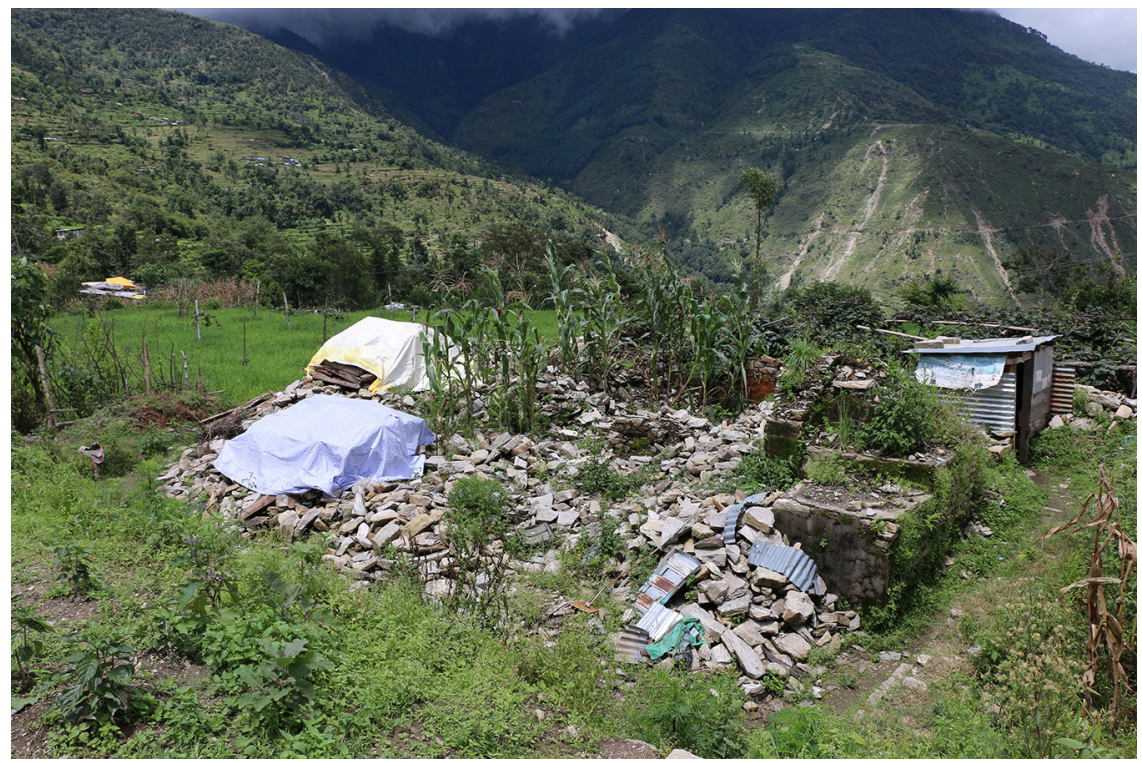

Figure 1. Corn growing in the ruins of a destroyed home: the work of disaster is also the gift of natality. Photo by Aidan Seale-Feldman.

\section{"A BOON FOR MENTAL HEALTH IN NEPAL"}

Although a mental health policy had been drafted and endorsed by the government of Nepal in 1997, it had never seen implementation (Luitel et al. 2015). Two decades later, mental health had not yet been fully incorporated into the health care system, and at the time of the earthquake, the Ministry of Health and Population had no mental health representative (Luitel et al. 2015, 5). This would become a problem for humanitarian mental health interventions in the aftermath of the earthquake, which had to contend with the fact that they would be providing people with brief access to care in regions that otherwise did not have such resources regularly available. Although three major global mental health projects had been working toward the goal of incorporating mental health into the primary health care system in partnership with the government of Nepal, psychiatric services remained concentrated in the capital city of Kathmandu and in select district 
hospitals. Outside of these institutional resources, temporally finite donor-funded community mental health programs implemented by Nepali NGOs provided access to care in some districts, a situation best described as a form of "transnational governmentality" (Ferguson and Gupta 2002), in which an uneven assemblage of foreign donor-funded NGOs provide state services. Similar to post-crisis psychosocial interventions elsewhere (James 2010; Abramowitz 2014), these programs focused largely on so-called victim groups, such as those subjected to gender-based violence, ex-child soldiers, or people impacted by the decade-long People's War, the Maoist insurgency that stretched from 1996 to 2006 demanding an end to the "semi-feudal/semi-colonial system" that had kept the rural poor, low-caste, and indigenous groups trapped in cycles of debt through high-interest loans and exploitative patron-client relations (Bhattarai 2003). From this point of view, state-led mental health governance in Nepal had been in crisis for a long time, but it had not been widely critiqued as such in public discourse.

The shift of attention toward mental health governance was generated by the work of disaster. In the context of disaster studies, scholars have shown how societies have unevenly transformed in the aftermath through increased nationalism, development, militarization, and privatization (Klein 2007; Gunewardena and Schuller 2008; Pandolfi 2010; Adams 2013; Choi 2015). Just as extreme flooding was mobilized to pass a new constitution in Venezuela (Fassin 2012, 181), in Nepal the disaster served as an impetus to promulgate the constitution after years of deadlock (Ruszczyk 2018), generating protests by Madhesi activists who argued that their region had not been granted full rights to self-determination. A critical issue at stake in such uses of disaster concerns the ways in which certain transformations and visions for the future become prioritized and supported while others are not (Lovell 2011; Simpson 2014, 31). As I will show in the following section, the strategic use of crisis to support predefined development goals also proved the case for mental health in Nepal.

In May 2015 the international news media began reporting on Nepal's "mental health crisis" (Bennett 2015; Stockton 2015; Nyenhuis 2016). According to these publications, the impact of the disaster would cause widespread trauma, with increased risks of PTSD and depression. From this perspective, it was a pre-accepted fact that trauma generated by the disaster would be minimized through immediate emergency psychosocial intervention. The sense that mental health was now in crisis was palpable in Kathmandu, where an unprecedented amount of activity and attention gathered around this new "matter of concern," enabling the crisis of mental health to emerge as a "matter of fact" (Latour 2004, 235). As Peter 
Redfield (2005, 337) writes of humanitarian intervention more generally, "once a state of crisis has been established, then action (especially technical, expert action) acquires self-authorizing status by virtue of circumstance."

Prior to the earthquake, I had been conducting research among Nepali NGOs for mental health and counseling in Kathmandu. At that time, eight years after the end of the People's War, the gold rush of donor-funded projects related to the conflict had largely run dry. Beyond the NGOs directly connected to the Movement for Global Mental Health (MGMH), there was little activity, with the exception of a handful of development projects that had incorporated a psychosocial component. After the earthquake, almost every psychiatrist and counselor I knew in Kathmandu had become directly involved in the humanitarian response. The mental health NGO offices pulsed with frenetic activity as project managers from donor organizations arrived to negotiate contracts. During this period the demand for psychosocial counselors was so high that there were not enough trained and qualified people to staff all the new projects and jobs that had suddenly appeared.

In the months following the 2015 earthquake I began to hear talk of "building back better" among my Nepali colleagues, and we wondered what this unprecedented flood of resources would mean for the future of mental health governance in Nepal (Seale-Feldman and Upadhaya 2015). In the context of the humanitarian mental health and psychosocial response, there was much discussion of this topic in the weekly Mental Health Sub-Cluster meeting. The meeting was run by the United Nations Office for the Coordination of Humanitarian Affairs (OCHA) and held with the hope of coordinating and documenting the array of almost seventy foreign and local organizations providing a range of mental health and psychosocial interventions, from psychiatric treatment, psychosocial counseling, and psychoeducation to community theater and anonymous phone hotlines. As the group began to form over the following months, it became a place where Nepali and expatriate mental health specialists - psychiatrists, NGO staff, development workers, humanitarians, activists, and even anthropologists — would not only report their activities but also imagine together what the future of Nepal's mental health system could be. So much money was flowing into post-disaster mental health and psychosocial support programs for earthquake victims that it seemed almost anything was possible. As one Nepali psychiatrist exclaimed to me in the Mental Health Sub-Cluster meeting, "The earthquake has been a boon for mental health in Nepal!" What does it mean for a disaster to be a boon: a godsend, a blessing, a bonus?

That crisis generates transient care is a well-known observation not only among anthropologists of disaster and humanitarianism (Redfield 2005; Ticktin 
2011) but also among practicing medical humanitarians. In the influential 2013 publication titled "Building Back Better: Sustainable Mental Health Care after Emergencies" (the key document and reference point to which my Nepali colleagues were referring) the World Health Organization (WHO 2013, 3) urges readers to take situations of emergency, crisis, and disaster as an "important opportunity for mental health reform and development." These goals, inspired by the Movement for Global Mental Health, would soon find alignment with the World Bank's vision of making mental health the next major international development priority. The authors of the document argue that increased international attention during situations of crisis enables aid to flow, and that this paradox should be seen as an opening. The report goes on to describe cases of building mental health systems in times of emergency, drawing on examples from the West Bank and Gaza, Sri Lanka, Iraq, and Indonesia (Aceh), among others. The message is clear: when mental health becomes a political issue in times of emergency, it should be seen as an opportunity to create sustainable forms of systemic change via humanitarian intervention. As the authors of the report put it, "in some countries, senior government leaders express — for the first time — serious concern about their nation's mental health. This is frequently followed by national and international agencies' willingness and financial ability to support mental health and psychosocial assistance to affected people" (WHO 2013, 17). As Mark van Ommeren, an influential global mental health scholar-practitioner and coordinator of the "Building Back Better" report said in a 2016 interview for Reuters, "the interest in mental health in and after an emergency is enormous. It's not surprising to see that the countries who have made the greatest progress in mental health system development are those that have been through emergencies" (Whiting 2016). Here the biopolitical logics of humanitarian reason, in which increasingly spectacular events of suffering are required to "make live," become clear (Foucault 1990, 2013; Povinelli 2011). But what counts as a spectacular event of suffering? Lauren Berlant (2011) and Elizabeth A. Povinelli (2011) have pointed out that there are "genres of event" and technologies of measurement that shape the way a given situation is perceived as a crisis or not, an objectification that determines who and what is worthy of care and intervention or subject to abandonment. In this way they draw our attention to the becoming of an event and the ways such becomings are grasped and perceived through predetermined frames of eventfulness.

This way of thinking of event and crisis, I argue, is deeply phenomenological. Phenomenological anthropology is an approach most often used in relation to questions of illness, healing, morality, and ethics that has contributed careful studies 
of embodied, lived experience and the ways such experience becomes objectified and made meaningful intersubjectively (Desjarlais and Throop 2011). While some have called for a "critical phenomenology," the study of experience as it takes form within social, historical, and political-economic contexts of inequality (Desjarlais 1997; Willen 2007), its application has largely focused on the first-person, subjective, experiential domain. In the anthropology of disaster, those who have engaged a phenomenological lens have also focused on experience (Hastrup 2011; Desjarlais 2016). ${ }^{5}$ Yet lived experience is not the only use to which we may engage this mode of analysis. Critical phenomenology, I argue, may also be used to analyze the designation of a given phenomenon as an event or as being in crisis. In such analyses a phenomenological perspective makes it possible to attend to the "politics of the a priori," that is, to how preconceived understandings, genres, and frames create but also foreclose possibilities for things to become otherwise (Zigon 2018). In this way, this article contributes to phenomenological anthropology by extending its application from studies of the body and experience to the phenomenology of disaster.

\section{THE WORK OF DISASTER}

In August 2015 I put my original research questions on hold to contribute to the humanitarian response. This decision was borne through a feeling of helplessness, a desire to make anthropology useful, and an invitation by a foreign development worker in charge of a psychosocial intervention. I joined the team of the Centre for Mental Health and Counselling-Nepal (CMC), a leading Nepali NGO that had been subcontracted by multiple foreign donor organizations to heal trauma among disaster-affected populations. In this role my fieldwork was transformed from classical ethnography and participant observation to a collaborative and engaged mode of cocreation (Lassiter 2005). As an "ethnographic consultant" for CMC, I attended trainings for supervisors, counselors, and community psychosocial workers, participated in meetings, attended the UN cluster meetings for mental health and counseling, and over the course of a year, accompanied three psychosocial counselors into the earthquake-affected districts to observe their interventions with individuals and communities. My observations and documentation were then taken back to the NGO, which used them in training workshops for Nepali supervisors, led by a foreign psychologist, and in training sessions for psychosocial counselors, led by the Nepali supervisors. Sharing my reflections and notes on various interventions did not prove easy, as my observations often operated in a mode of critique. But the negotiation of interpretation across all levels of 
the organization was the aim, and my observations and data served as a foundation from which we built more engaged practices of support for counselors in the field. ${ }^{6}$ Drawing on this aspect of my research, in the following sections I introduce four vignettes that demonstrate how forms of suffering that predated the disaster became visible through the event and its transient ethical demands. In doing so, each story shows the ways in which a priori frames of crisis, "the better," and earthquake-related suffering created and foreclosed possibilities for care and for building back otherwise.

The otherwise has emerged as a hope-filled concept in the wake of what Sherry B. Ortner (2016) has referred to as decades of "dark anthropology," for it allows us to move beyond the paralysis of critique and sketch a politically engaged path toward what is not yet. Povinelli (2011) first described "the otherwise" as forms of alternative social projects that emerge and endure in the unlivable and lethal spaces of late liberalism. Such projects may be organized modes of resistance or simply found in the act of maintaining a particular form of life when faced with its possible extinction. While Povinelli $(2011,129)$ locates this radical otherwise in "scenes of abandonment," she also questions the implications of positing a form of world-making created by lethality. Alternately, in Jarrett Zigon's (2019, 20) work with anti-drug war agonists, the otherwise marks neither a rupture with the past nor utopia, nor even something that is necessarily "better" than what came before. Instead, thinking with Giorgio Agamben, Zigon argues the otherwise is something that sticks and endures through "tiny displacements" over time. Yet his spaces of otherwise experimentation also come into existence in connection to the drug war and its deadly effects - if not inside it, then in clearings along its edges. Like the sudden surge of care and concern inaugurated by the work of disaster, the potential for the emergence of an otherwise is always found in relation to the threat of death.

\section{The Better}

In Nepal, while the majority of the humanitarian mental health programs operated for less than a year, some international donor agencies, informed by the "Building Back Better" report, saw the disaster as an opportunity to initiate longterm programs to support the development of the mental health system, blurring the boundaries between humanitarianism and development, emergency response and long-term investment (Ticktin 2014). The International Medical Corps (IMC), with funding from corporations, foundations, U.S. government grants, and \$10 million generated from 500,000 individual donors on Facebook, became a key ac- 
tor in both short-term humanitarian mental health and psychosocial support as well as long-term development work. In addition to working in Nepal, IMC had also supported programs to integrate mental health into primary health care in Iraq, Jordan, Lebanon, Syria, and Turkey (IMC 2015).

Back in the cluster meetings, a troubling issue began to surface, the problem of the homeless mentally ill who in Nepal were at that time unable to receive medical services without a guardian willing to take responsibility for them, a prerequisite for hospital care. The only existing help for this group of people was a Nepali NGO, run by a man named Vivek Ji, ${ }^{7}$ who brought the issue to the table. Vivek Ji is a well-known mental health activist in Nepal. I saw him regularly at both the Mental Health Sub-Cluster and the Psychosocial Working Group, and he would continually bring up the problem of the homeless mentally ill in both groups. When he did so, he would often be met with silence. Everyone enthusiastically agreed it was a problem, but what could be done? In the Mental Health Sub-Cluster meeting one of the humanitarians working with IMC mentioned that there might be a possibility of securing money to work on the issue. The group unanimously decided to form a working group to tackle the subject, and I, too, offered to help in drafting any reports or documents they might need. A palpable sense of excitement took hold. "You must strike while the iron is hot!" said a Nepali woman in attendance. The facilitator of the group also approved of the idea, and it seemed that maybe

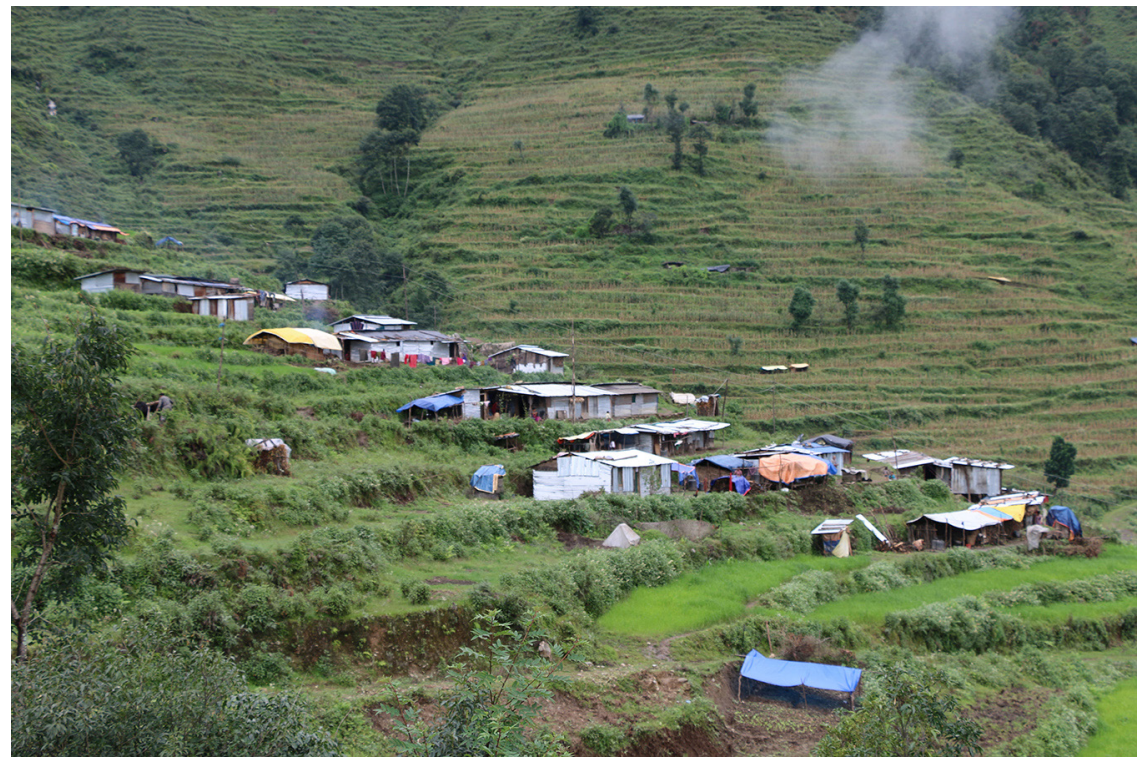

Figure 2. The temporary shelters of resettled families. Photo by Aidan Seale-Feldman. 
the right people with enough power could also be brought into the conversation. But, in the end, the representative of the humanitarian donor organization announced that funding could only be allocated for earthquake-related mental health issues. Yet even after this failure, Vivek Ji continued to advocate and raise critical questions. "What will happen to the abandoned children with mental disabilities? What will happen to the abandoned adults with severe mental illness?" he asked the room full of humanitarians. The facilitator of the meeting looked at him solemnly and said, "We don't have the capacity ..." Who and what qualified as an earthquake-related mental health issue? The answer was not at all clear. The ongoing problem of the homeless mentally ill that had suddenly resurfaced remained beyond the scope of the humanitarian intervention, even among those engaged in the project of "building back better." And yet, although a priori frames limited care, they also created the conditions for its emergence.

\section{The Limitations and Possibilities of Transient Care}

The psychosocial counselors and I arrived at a green hillside in Dolakha District dotted with tin shelters, so that Indira could conduct a group counseling session with the members of a highly earthquake-affected community. Unlike other places, this community had not only lost their homes, but they had been resettled to an entirely new area of land due to the risk of landslides. On arrival, Indira explained the intervention to a confused and weary crowd. Why had she come? What relief materials would she be providing, people wondered aloud. "We won't be bringing you relief, nor any GI sheets," said Indira's assistant. "We won't be bringing tarpaulin. We don't have all these things. We are here to bring relief to the hearts of all those who have problems. . . Know it well that we don't have any relief materials. Look, we have come empty handed." "It's only for psycho counseling," a local man explained to the group. "They are not here to corrupt your minds. They are here to help you to spread public awareness. Their objective is to increase your confidence. That's why we should cooperate with them," he added.

With each new visit, psychosocial counseling had to be explained in lay terms. A group of twenty, mostly women, had assembled in a circle beneath a tin shelter. The counselor, Indira, who had grown up in this district and had made a career of her work as field staff on donor-funded health-development projects, asked, "how is your man doing?" and instructed people to go around the circle and share with each other how they were feeling and enduring their loss. Man, a Nepali-language term, is often translated into English as "heart-mind." The concept of man collapses thought and feeling, and is the site of desire, intentional- 
ity, mood, opinion, delight, and dislike (Turner 1965; Desjarlais 1992; Kohrt and Harper 2008). Too much activity in the man can lead to suffering and anguish, thus inspiring the translation of "psychosocial counselor" as manobimarshakarta, or "one who advises on matters of the heart-mind" (Kohrt and Harper 2008, 484). After each person shared a brief story of suffering, Indira would comment on their words, praising them for their ability to imagine concrete plans for the future if they did so, and asking the group for a round of applause for particularly optimistic, self-motivated individuals.

As Indira went around the circle, people spoke of worries about being able to pay their debt, about their children's education having been disrupted (literally "broken," bigreko), about their crops that were harvested but beginning to rot in the damp, makeshift shelters. Many had sons and even daughters working abroad in India, Malaysia, or the Persian Gulf, more had thoughts of sending their children abroad in hopes to make some money to somehow start again. They worried about how they would feed themselves. Consolation came in the form of hope that maybe the government, some organization, or project would help them, and a sense of comfort in the fact that at least everyone had suffered from the disaster, not just one person. People spoke of what they had undergone, of what they had lost, as their karma, as one's fate that was already "written," lekheko.

What kind of care was possible in the midst of so many limitations - economic, infrastructural, geological, temporal — and what did such care look like? Three months later I returned again to Dolakha with Indira. This time it was winter, and Indira was bundled in a puffy jacket and knit hat to fight the biting cold. Searching for clients to follow up with, Indira found a young man she had met twice before. They sat, legs crossed, on a woven mat in front of the corrugated tin wall of his makeshift shelter. It was their third meeting, and Indira began by saying, "The other day we spoke. After the conversation, I see that your face has become a little brighter, ujyaalo. You look happy. Is my guess correct?" Neither confirming nor denying her observation, the young man began to talk about how he felt everything was worthless. He explained that his problems started while he was working abroad as a labor migrant in the Persian Gulf, one of the few viable possibilities for employment available to Nepalis from lower socioeconomic backgrounds. Life as a labor migrant in places like the Gulf and Malaysia is often brutal and sometimes deadly, as workers are confined to labor camps where they earn low wages, exercise little freedom, and are often exposed to dangerous working conditions of extreme desert heat (Bruslé 2012; Pattisson 2013). While this client was abroad, his fear of heart attack was so great that he sometimes could not get 
out of bed. He told Indira with sincerity, "my biggest medicine is alcohol. I have started drinking it not for taste, but for treatment." Indira did not hide her disapproval.

Toward the end of their meeting, Indira's client told her directly that he would like to have more treatment, and asked if he could go with her somewhere to access additional care. "OK," she responded. "We have already talked two to three times with you. If you want to talk more with us, then we have a one-year program here, so we will talk to you again.” It was a moment of relief as she announced the program had been extended for one year. But what will happen after a year has passed, and she can no longer make promises of return? As long-term suffering became visible over the course of the intervention, it had to be treated with transient care due to the limitations of a priori frames of crisis and humanitarian intervention.

Many clients, particularly those who described prior symptoms of psychosis or epilepsy, said that medication had helped them improve. In another district, Bina, a second psychosocial counselor with whom I worked, met with a middle-aged man who, prior to the disaster, had largely abandoned his daily farming tasks and family responsibilities and begun to wander incoherently in the nearby forest, a form of madness known as jangali. We met with him in the upstairs room of his mud home, which had survived the earthquake. A month had passed since he had been prescribed Olanzapine $5 \mathrm{mg}$, an antipsychotic, and Fluoxetine 20mg, an antidepressant, by the NGO, two medications he took along with his own Memtone Memory Tonic, an Ayurvedic medicine for "memory loss, stress, depression, headache, sleeplessness, anxiety and forgetfulness." The man spoke as if heavy with sleep. Bina listened patiently, often repeating back the phrases he said to her as if checking that she understood correctly.

"After meeting you and talking with you, and after taking the medicine, I am feeling a little better," he said slowly. "And after having more medicine, I believe that I will be cured.”

"That's very good thinking," Bina replied. "So you are feeling better and comfortable after talking to us and taking medicine?"

"Yes," he answered.

Bina neither confirmed nor denied his belief in a cure, although it is likely that without the program, his access to medication would be greatly limited. On the day of the session, he informed Bina that he had only one more dose of medicine left. 
In this particular program, clients who counselors felt might need medication were taken to Kathmandu where they would meet with the NGO psychiatrist for a consultation. Once the psychiatrist had given a diagnosis, clients were eligible to receive their medication free of charge through the NGO. Back in the villages, they either had to purchase their own medication and submit receipts for reimbursement or the local community psychosocial workers were expected to be notified ahead of time to deliver the medication to clients. But when the program phased out, this access and monitoring would also disappear. Even during the program, unless a client started looking for more medication at least ten days before it ran out, it was not guaranteed that the medication would actually be available in a nearby pharmacy, nor was it guaranteed that the available pharmaceuticals would be of trustworthy quality due to the lax regulations of the off-patent formulations that dominate the market in Nepal (Harper, Rawal, and Subedi 2011, 6). The availability of drugs (along with fuel, cooking gas, and construction materials) became further limited when violent political protests over the new constitution erupted in the Madhesh region of the southern Terai, causing India to endorse a four-month unofficial blockade at the border from September 2015 to February 2016, and sending Nepal into a spiral of scarcity. The possibility that clients might be left without access to medicines after humanitarian care ends is one of the key reasons driving the "Building Back Better" model. The hope is that if lasting mental health infrastructure can be built in the midst of emergency, then people

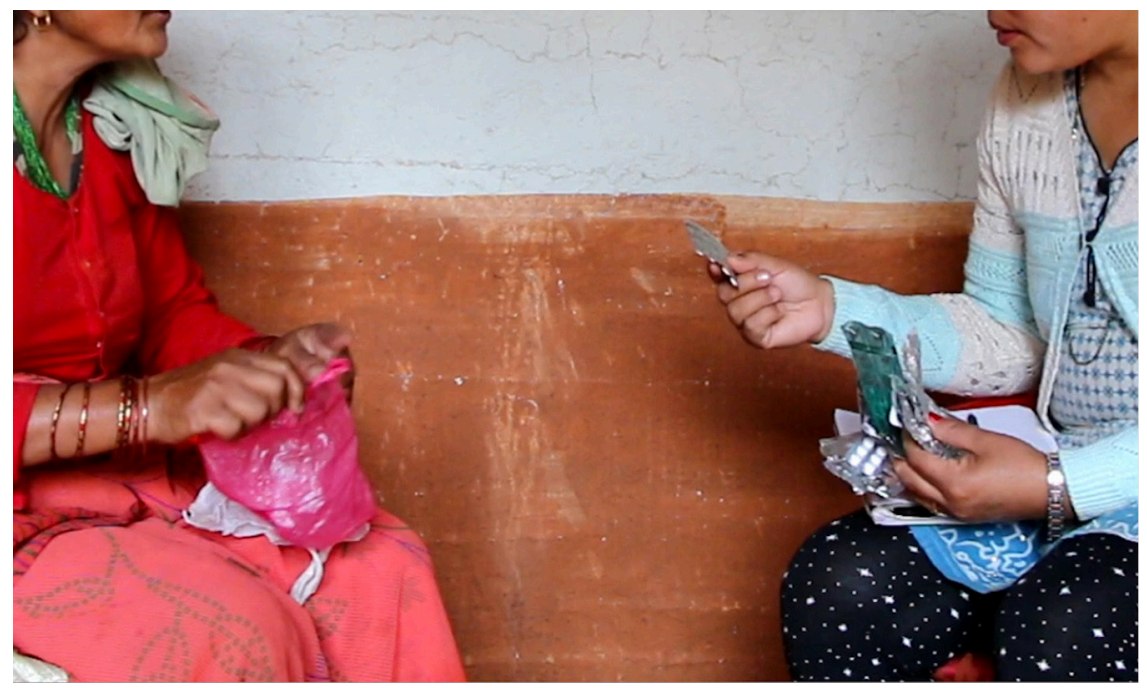

Figure 3. A counselor helps a client sort out new medication. Photo by Aidan Seale-Feldman. 
will continue to have access to medication even after the end of humanitarian intervention.

\section{Mundane Disasters of Everyday Life}

We hiked down the dusty trail of a steep hill to reach the still-standing mud house of an elderly woman, Ganga Maya. It was the second time Bina had met with her. Tara, the community psychosocial worker (CPSW) a local resident, herself living in a transitional shelter made of corrugated metal, led us to Ganga Maya's home. Bina and Ganga Maya sat cross-legged on a woven mat on the floor inside her modest house. The mud walls were painted in a classical style, red mud on the bottom, white mud on the top. "Namaste, Aamaa," Bina said, her hands held together in prayer, the typical Nepali greeting. Compared to Bina's robust health, Ganga Maya's body was small and thin. Her face held a sorrowful expression, and her eyes were downcast. "How are you feeling today?" Bina asked. Ganga Maya replied, "You all came, so now my heart-mind, man, is a little refreshed, sital."

"I don't know what to do," she said to Bina. "I am sick. I just sit and cry. What can I do, ke garne. I belong to a poor family. We have to work for our livelihood. So I work here and there. This is reality. What to do. Whatever is written we have to face it, right? I have children but no one is here with me. I don't know where they are. I stay here alone.”

Ganga Maya had recently tried to commit suicide in the nearby river. She was saved by people nearby who pulled her out of the rushing water. She told Bina that her husband was often away at work, and that he rarely came home except to sleep. She proceeded to tell the following story.

My husband has a very bad habit of talking bitterly. That's the reason I don't want to stay here. I get pain in my lower abdomen. I pulled the placenta myself ... . I get pain while with him as well. If I say I cannot do it, he gets angry. That's why I cannot tell him that. So I want to stay away from him, and sometimes I feel it would be better if I die . . . it's been a very long time. That happened when I gave birth to my third son. He is now sixteen years old. Labor started at noon and I gave birth at midnight. At that time nobody took me to the hospital and no one gave me any medicine. The newborn was in front of me. He was crying and his lips were getting dry and blue. So I didn't care about the consequences and pulled the placenta to separate the baby. When I pulled, everything came out. Then with the help of another woman, I put everything back in myself. 
Ganga Maya told Bina that although she had seen a shaman, dhami, about her problem, her husband did not support her seeing a doctor. "A daughter's karma is a life already lost [choriko karma hareko juni]," she explained, quoting a well-known Nepali proverb and critique of the ongoing power of patriarchy. Later Ganga Maya continued. "I wish I didn't worry so much. I am taking medicine for that. But when I had that medicine, I used to fall asleep everywhere."

"Did you take the medicine after proper consultation with a doctor?" Bina asked.

"No, without any consultation. We were talking just like this. I told my problem, and they gave me the medicine." Ganga Maya had been prescribed Amitriptyline $25 \mathrm{mg}$, an antidepressant, by another NGO also providing mental health and psychosocial care in the earthquake-affected district.

Ganga Maya's story of suffering occupies a different kind of temporality. It does not describe a sudden disaster in which everything is lost; instead, she speaks of something slower. These are the mundane disasters of everyday life - an abusive relationship with her husband, severe pain due to untreated uterine prolapse, and the sadness of family conflict. According to her narrative, her physical suffering had gone untreated for sixteen years. Suddenly, after the event of the earthquake, multiple psychosocial counselors came to her home to provide counseling, antidepressants, and support to travel to a hospital. Her everyday suffering had become hypervisible through the frame of crisis. ${ }^{8}$

The widespread use of medication by clients in the psychosocial intervention program also pointed to an unexpected aspect of the humanitarian intervention as a whole. While clients seen in group sessions in the immediate aftermath of the earthquake described problems that had a clear connection to the disaster, the majority of those seen over the following eighteen months were being treated for problems, sometimes serious mental illness, that predated the earthquake. While the earthquake undoubtedly placed these individuals and their families into situations of further precarity, their suffering had only become visible through the work of disaster and its ethical demands. The "right to intervention," justified on the basis of "superior ethical principles" and predefined universal values (Hardt and Negri 2000, 18), has also produced a contemporary situation in which spectacular crisis is required for care, and a disaster might become a boon. This is the specter that haunts humanitarianism. 


\section{The End of Care}

Phul Kumari, age eighty-one, sat on the ground in the courtyard in front of the ruins of her home. She said that she felt afraid that she would die in her sleep by being crushed by the remains of her house. She was less worried about dying per se than about dying a slow and painful death. Her problem, she said, was that her sons, who lived on the same property, had not built her a shelter to stay in, and she had not been invited to stay with them in theirs, so she remained alone inhabiting the ruins of her home. Her family problems stretched back many years to a feud over land holdings. Phul Kumari told us again and again that she felt alone. The last time she met with Bina, she told her that she wanted to kill herself, that she was thinking of jumping off a cliff, or of hanging herself. But that she was worried about what people would say about her. She said these thoughts come to her, gesturing at her chest. Bina was attentive. She sat close to Phul Kumari and leaned her body toward her. When the old woman told her that she had recently fallen, Bina took her hand to examine the swelling. Phul Kumari called her babu, child, and Bina called her aamaa, mother.

Toward the end of the session, Phul Kumari told Bina, "You talk so nicely and politely. You talk in such a way that you show me reality like in a mirror," she said as she spread her hands across the ground in front of her. "When you talk I feel that I have everyone, my children, my relatives, and my grandchildren. I feel like my heart has broadened with joy, it is like a nanglo [a large round rice-winnowing pan]. When you leave, it is again the same loneliness." Responding to this direct comment on separation and the end of care, Bina suggested, "There is an old saying that 'even a ghost that is close to us is more helpful than a distant god,' tadako deuta naajikko bhut kaam laagcha." "Yes, that's it, babu," Phul Kumari agreed. "Distant gods . . . ghosts close by . . the ghosts close by are more useful." "Yes," said Bina. "We are distant, hami tadako ho." "We will visit you when we can."

After the earthquake, psychosocial care in Nepal was unevenly distributed and always constrained by the timeline set by the donor agencies in which "victimhood" required a practical endpoint. In the psychosocial support cluster meetings in Kathmandu, humanitarian partners were reminded to make a "dignified exit." Even the most sensitive and engaged foreign project managers could not escape the constraints of the logics of their field (Fassin 2012) — whether development or humanitarian - in which "phasing out" was always required. On the ground, counselors seemed to avoid discussing the possibility of the project ending with their clients, an unpleasant truth no one enjoyed speaking about. When I asked, in the NGO headquarters in Kathmandu, what would happen to clients who had 
been prescribed free psychotropic medication once the project came to an end, the Nepali project supervisors could not answer with clarity. Ultimately, the duration of the program was out of their hands. As one NGO officer said to a group of counselors during a training, "Donors bhane [say], 'beggars can't be choosers" that is, NGOs cannot control how long a project exists.

By December 2015, the cumulative reporting from the child-protection sub-cluster announced that more than three hundred thousand "beneficiaries" had been provided psychosocial support services by more than sixty-six organizations (United Nations Children's Fund 2016). In the first months following the earthquake many people spoke in group sessions about their fear, confusion, sorrow, loss, and somatic pain. Six months later, the focus had switched from the group to the individual, and the majority of people seen were not suffering from problems directly related to the disaster. These were people who had been suffering all along from the slow disaster of poverty, from the mundane disasters of everyday life such as abuse in the family or the anxieties of labor migration, from severe mental illness, from ghosts or witchcraft (boksi laagne/chopne), or from a combination of these. The disaster and their categorization as earthquake victims had temporarily rendered their suffering visible, and in their brief visibility they received transient care.

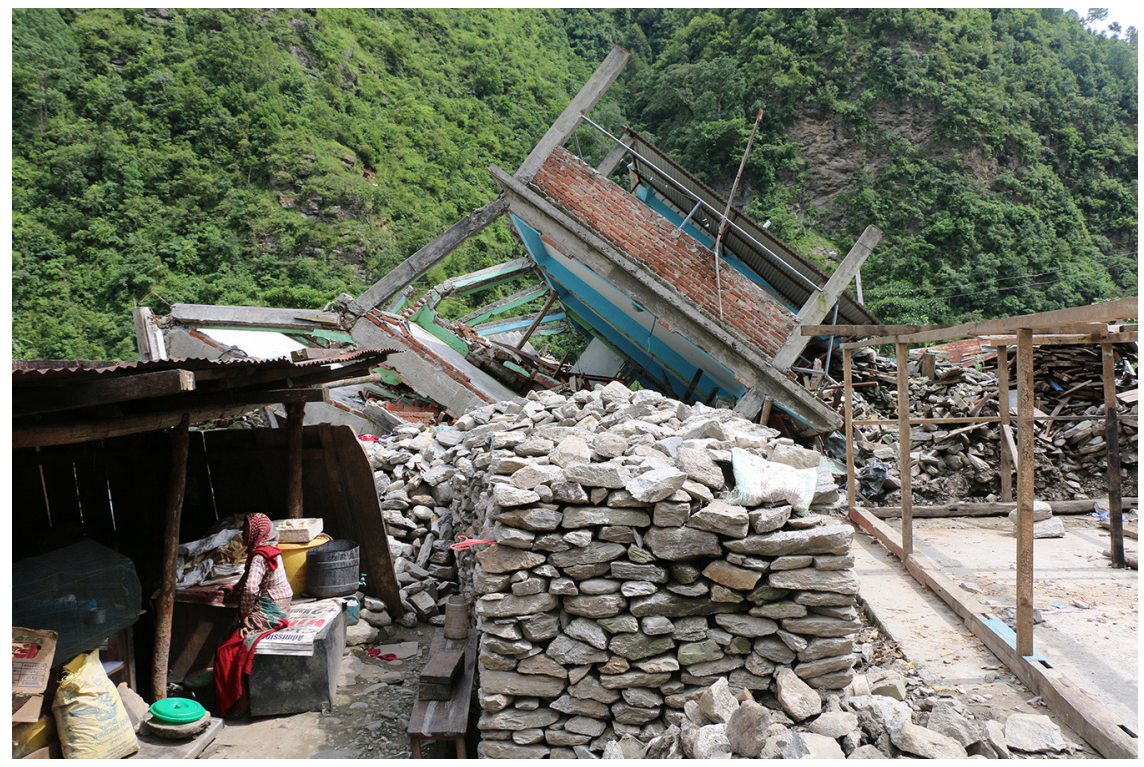

Figure 4. Waiting to rebuild. Photo by Aidan Seale-Feldman. 


\section{CONCLUSION: BUILDING BACK OTHERWISE}

The seismic event set the work of disaster into motion. Its designation as a crisis worthy of care inspired people from all over the world to donate money. Humanitarian agencies like IMC used the sudden increase in national and international attention and resources to fast-track prior development goals of improving the mental health system in Nepal. The WHO prepared the "Building Back Better" policy so that when a situation of crisis is designated as such, previously determined development priorities can be pushed through. The policy anticipates the crisis as an opening, a possibility to create further infrastructure, in this case, mental health governance. In this way, international development actors like the WHO and their partners predetermine "the better" to be built.

The earthquake was a boon for mental health governance in Nepal: many aspects of the country's mental health system have seen development because of this policy. Additional psychotropic drugs have been added to the free drug list, and the government has for the first time created a budget for decentralized mental health care (Chase et al. 2018, 10). Yet it is also important to point out the limitations of having a predetermined understanding of the "better." The work of disaster is a powerful process by which a world is destroyed and then must be rebuilt. But ultimately what is rebuilt does not particularly differ from what came before. When the "Building Back Better" report states that "global progress on mental health reform would happen more quickly if, in every major crisis, strategic efforts were made to convert short-term interest in mental health problems into momentum for mental health system development" (WHO 2013, 20), we begin to see how such plans for global reform already directly align with broader World Bank priorities.

In 2016 the World Bank, in partnership with the WHO, held a high-profile event titled "Out of the Shadows: Making Mental Health a Global Development Priority.” The inaugural panel framed mental health not only as a universal human right but also as a major constraint to development. Citing figures showing that mental illness is the leading cause of years lived with disability (YLDs), it was announced that "the global cost of lost productivity due to mental illness amounts to . . . the equivalent of US\$1 trillion dollars per year" while every dollar invested in the treatment of depression and anxiety yields a four-dollar return in better health and the ability to work (World Bank Group and WHO 2016, 6). The role of the World Bank in this new global crisis will be to provide funding and technical support to help decrease the prevalence of mental illness in resource-poor countries, with the goal of increasing economic productivity. As the management of mental 
illness in populations becomes justified in economic terms, the old link between biopolitics, capital, and the economization of life becomes clear (Foucault 2013, 65). Yet it is unknown what would happen to these newly productive citizens in Nepal, a country with few existing opportunities for employment. In 2018, 28 percent of Nepal's annual GDP was generated from remittances, placing it among the top six remittance-driven economies in the world (World Bank n.d.). This article should not be read as a critique of the need for access to care in Nepal. Far from it. Instead, it offers an inquiry into the forms of suffering that are grasped, and the preconceived notions of "the better" that are employed by development agencies, and how these frames limit but also enable possibilities for care and an otherwise to come into being in surprising places.

It is this latter point that directs our attention to the possibilities of care and formations of the otherwise brought about by the work of disaster. It is not only through the future-oriented project of world-building but also in the present moment of being together that we glimpse the otherwise-if only for a fleeting moment. As Phul Kumari said to Bina as they sat together facing the end of care, "when you talk I feel that I have everyone . . . I feel like my heart has broadened with joy ... when you leave, it is again the same loneliness.” There was a beginning and an end to care, which did not neatly align with the temporality of suffering for clients. This was patchwork care, in the same way people in Kathmandu were said to have patched up the cracks in their concrete homes with putty and plaster, without rebuilding the structural damage beneath. But the counselors were not entirely limited by the logic of humanitarian care within which they found themselves. For Bina and Indira it offered an opportunity, also transient, and they tried to do good with what little they could offer under the circumstances. Through the course of a given counseling session, care might be extended through touch or a certain turn of phrase, through the delivery of medication, through an insistence that one had improved, through a guided breathing session, or simply through an acknowledgment that one person had traveled a great distance to listen to the worries of another - that after the world had been destroyed, a stranger had walked and suffered for them. Yet just as quickly, a moment of care and connection between counselor and client could dissolve into disconnection, a touch could be withdrawn, a judgement made, a face turned away.

In the work of post-disaster psychosocial counseling, three temporalities were braided together. The first strand was the temporality of humanitarian care, defined by its transience. The second was the temporality of suffering, one that often predated the disaster and would certainly outlast this transient care. The third 
temporality was that of karma, in which suffering was placed in a far longer duration. Clients would talk about their dukkha, their suffering, as their karma. "Whatever is written we have to face it," as Ganga Maya put it. In the Nepali language, shaped by the religious philosophy of both Hinduism and Tibetan Buddhism, one's karma, or fate, is inscribed, written, lekheko, on one's forehead at birth, nidaama lekheko. In such karmic temporality, the present links directly to actions done in a previous life (Desjarlais 2016). In the psychosocial counseling project, these three temporalities coexisted simultaneously, often in the same moment. Within this braid of time the otherwise came into being.

The otherwise is not a future dream: it is already with us. The possibility for an otherwise to emerge is always already there as a potentiality in the intersubjective space between us. We can find it in moments of care that instill small changes in the present and continue to live in memory, no matter how transient or precarious the conditions of their creation. "After meeting you and talking with you, and after taking the medicine, I am feeling a little better . . . I believe that I will be cured," said the middle-aged man to Bina. This otherwise is not the grand plan of "building back better," but the small mark left on a single life that has been touched by the concern of another. The question is how we might intentionally cultivate otherwise encounters that do not depend on threats of annihilation and temporalities of crisis to bring them into existence. As Bina reminds us, "the ghosts close by are more useful than distant gods," for they are always already beside us. To build back otherwise beyond the temporality of crisis would be to find a way to sustain this ethics of care with each other and with the world - which may be generated by the work of disaster but does not depend on it.

\begin{abstract}
What does a disaster generate? This article brings a critical phenomenological approach into conversation with theories of event to trace the emergence of a mental health crisis and its consequences in Nepal after the 2015 earthquakes. Following the disaster, people who received psychosocial counseling often presented chronic problems that had become visible through the frame of crisis and its ethical demands. At the same time, humanitarian agencies were aware of the logics of crisis and strategically used the disaster as an opportunity to increase mental health governance under the rubric of "building back better." I demonstrate that these phenomena are linked consequences of the work of disaster, the destruction and creation of worlds set into motion by disaster and its management. I argue that a phenomenological approach to disaster helps us attend to the ways a priori frames of crisis and "the better" create and foreclose possibilities both for care and for building the world back other-
\end{abstract}


wise. [disaster; crisis; care; critical phenomenology; biopolitics; global mental health; Nepal]

\section{सारांश}

विपदले के उत्पादन गई? २०१९ सालको भुकम्पत् निम्त्याएको मानसिक स्वास्थको संकट $₹$ नेपालमा त्यसका परिणामको उद्भव यस लेखले घटनाक्रियाविज्ञान (फेनोमेनोलोजी) र घटना सिद्धान्तको संवादबाट चित्रित गई। २०१९ को विपद पछि, जुन जीर्ण समस्याहरु मनोसामाजिक परामर्श पाउनेहरुमा देखा पर्यो, यी समस्याहरु संकटको धारणा र संकटको बेलाको नैतिक जिम्मेवारीको माध्यम बाट मात्र बाहिर देरव़ आइपुग्यो । त्यस समयमा मानवीय निकायहरुले पनि रणनीतिक तरिकाले विपदलाई मानसिक स्वास्थ प्रशाशनलाई अझ सहज बनाउने अवसरको रुपमा लिए, झन् राम्रो पुननिर्माण ('बिल्डिंग ब्याक बेट्टर') को शीर्षक मुनि । यी घटनाक्रम सबै 'विपदका काम' सित जुडेका परिणामहरु हन भनेर म यस लेखमा उल्लेख गछु, जहाँ विपद र विपदका व्यवस्थापनले नयाँ संसारहरुका बिनाश र सिर्जना दुबै भैरहेका छन् । संकट र 'झन् राम्रो' जस्ता पूर्वनिर्धारित अवधारणाहरुले कसरी हेरचाह र पुननिर्माणका सम्भावनाहरुलाई संगसंगै उत्पादन एवम सिमित गई्छन भनेर बुझ्न घटनाक्रियाविज्ञानको दष्टिकोणले सहयोग गई भन्ने मेरो तर्क यस लेखमा प्रस्तुत गरेकी छु। [विपद; संकट; हेरचाह; घटनाक्रियाविज्ञान; जीवराजनीति (बायोपोलिटिक्स); अन्तरास्ट्रिय मानसिक स्वास्थ; नेपाल]

\section{NOTES}

Acknowledgments This article would not have been possible without the guidance, friendship, and encouragement of Barbara Weyerman, Pashupati Mahat, Karuna Kunwar, Laxshmi Tamang, and everyone at the Centre for Mental Health and Counselling-Nepal, thank you for helping me discover new ways of engaging anthropology. I am especially grateful to Jason Throop, Sherry Ortner, Robert Desjarlais, Jarrett Zigon, Douglas Hollan, L.F.R. Murillo, Camille Frazier, and Devin Flaherty for carefully reading and commenting on various versions of this text at critical moments, as well as to my anonymous reviewers who helped sharpen my thinking. I am thankful for having had the opportunity to work with Chris Nelson, who provided incredible editorial care, insight, and guidance. Special thanks to Erica Adhikary and Pranaya Rana for help with complex translations. I also received valuable feedback from scholars at the UCLA/University of Amsterdam Conference on Crisis and the Everyday, Cermes3 in Paris, the 2016 American Anthropological Association Annual Meetings, and the UVA/Duke Writing Group "Formation, Deformation, Care," especially Anne Allison, Anne Lovell, Raphaëlle Rabanes, China Scherz, and Lisa Stevenson. This research was funded by the Wenner-Gren Foundation, the UCLA Center for the Study of Women, the UCLA International Institute, the UCLA Department of Anthropology, and the Foundation for Psychocultural Research - Culture, Brain, Development, and Mental Health Program.

1. This radio program fits into a longer history of the use of call-in FM radio programs and voice as a medium for public intimacy and the sharing of suffering, dukkha, in Nepal (Kunreuther 2014). 
2. Here I follow Veena Das $(2007,95)$ in her use of the term work and her discussion of the agency of time and temporality.

3. As Hannah Arendt $(1998,257)$ writes: "The miracle that saves the world, the realm of human affairs, from its normal, 'natural' ruin is ultimately the fact of natality, in which the faculty of action is ontologically rooted. It is, in other words, the birth of new men and the new beginning, the action they are capable of by virtue of being born."

4. A slogan coined by UN Special Envoy Bill Clinton following the 2004 Indian Ocean tsunami.

5. One exception is the call to study the temporality of catastrophe by Christopher Dole et al. (2015), which, while not described as a phenomenological approach, shares many of its sensibilities.

6. Additionally, I shared drafts of this article with members of the project so they could comment and edit. Every story I present here was discussed and presented to the organization for supervision and further training. All clients provided me with permission to record their counseling sessions, which I explained was for the purpose of my research and for understanding how to improve the work of the psychosocial counselors through further training.

7. I use pseudonyms for all personal names.

8. For a discussion of the intersection of eventfulness, slow violence, and precarity see Anne Allison (2013) and Megan Raschig (2017). For literature on "slow disasters," particularly in relation to toxic exposure, see Kim Fortun (2001); Max Liboiron, Manuel Tironi, and Nerea Calvillo (2018); and Rob Nixon (2011).

\section{REFERENCES}

Abramowitz, Sharon Alane

2014 Searching for Normal in the Wake of the Liberian War. Philadelphia: University of Pennsylvania Press.

Adams, Vincanne

2013 Markets of Sorrow, Labors of Faith: New Orleans in the Wake of Katrina. Durham, N.C.: Duke University Press.

Allison, Anne

2013 Precarious Japan. Durham, N.C.: Duke University Press.

Arendt, Hannah

1998 The Human Condition. 2nd ed. Chicago: University of Chicago Press.

Barrios, Roberto E.

2017 "What Does Catastrophe Reveal for Whom? The Anthropology of Crises and Disasters at the Onset of the Anthropocene." Annual Review of Anthropology 46: 151-66. https://doi.org/10.1146/annurev-anthro-102116-041635.

Bennett, Claire

2015 "The Nepal Earthquakes Have Unleashed a Mental Health Disaster." Guardian (UK), May 15. https://www.theguardian.com/commentisfree/2015/may/15/

Berlant, Lauren nepal-earthquake-mental-health-disaster.

2011 Cruel Optimism. Durham, N.C.: Duke University Press.

Bhattarai, Babu Ram

2003 “The Political Economy of the People's War." In The People's War in Nepal: Left

Bond, David Perspectives, edited by Arjun Karki and David Seddon, 117-64. New Delhi: Adroit.

2013 "Governing Disaster: The Political Life of the Environment during the BP Oil Spill.” Cultural Anthropology 28, no. 4: 694-715. https://doi.org/10.1111/ cuan.12033. 
Bruslé, Tristan

2012 "What Kind of Place Is This? Daily Life, Privacy and the Inmate Metaphor in a Nepalese Workers' Labour Camp (Qatar).” South Asia Multidisciplinary Academic Journal 6: 2-25. https://journals.openedition.org/samaj/3446.

Chase, Liana E., Kedar Marhatta, Kripa Sidgel, Sujan Shrestha, Kamal Gautman, Nagendra P. Luitel, Bhogendra Raj Dotel, and Reuben Samuel

2018 "Building Back Better? Taking Stock of the Post-Earthquake Mental Health and Psychosocial Response in Nepal.” International Journal of Mental Health Systems 12,

Choi, Vivian Y. no. 44. https://doi.org/10.1186/s13033-018-0221-3.

2015 "Anticipatory States: Tsunami, War, and Insecurity in Sri Lanka." Cultural Anthropology 30, no. 2: 286-309. https://doi.org/10.14506/ca30.2.09.

Das, Veena

2007 Life and Words: Violence and the Descent into the Ordinary. Berkeley: University of California Press.

Desjarlais, Robert

1992 Body and Emotion: The Aesthetics of Illness and Healing in the Nepal Himalayas. Philadelphia: University of Pennsylvania Press.

1997 Shelter Blues: Sanity and Selfhood among the Homeless. Philadelphia: University of Pennsylvania Press.

2016 Subject to Death: Life and Loss in a Buddhist World. Chicago: University of Chicago Press.

Desjarlais, Robert, and C. Jason Throop

2011 "Phenomenological Approaches in Anthropology." Annual Review of Anthropology 40: 87-102. https://doi.org/10.1146/annurev-anthro-092010-153345.

Dole, Christopher, Robert Hayashi, Andrew Poe, Austin Sarat, and Boris Wolfson

2015 "When Is Catastrophe? An Introduction." In The Time of Catastrophe: Multidisciplinary Approaches to the Age of Catastrophe, edited by Christopher Dole, Robert Hayashi, Andrew Poe, Austin Sarat, and Boris Wolfson, 1-18. London: Routledge.

Fassin, Didier

2012 Humanitarian Reason: A Moral History of the Present. Berkeley: University of California Press.

Ferguson, James, and Akhil Gupta

2002 "Spatializing States: Toward an Ethnography of Neoliberal Governmentality." American Ethnologist 29, no. 4: 981-1002. https://doi.org/10.1525/ae.2002.29.4.981.

Fortun, Kim

2001 Advocacy after Bhopal: Environmentalism, Disaster, New Global Orders. Chicago:

Foucault, Michel University of Chicago Press.

1990 The History of Sexuality, Vol. 1: An Introduction. Translated by Robert Hurley. New York: Random House.

2013 "Right of Death and Power over Life." In Biopolitics: A Reader, edited by Timothy Campbell and Adam Sitze, 41-60. Durham, N.C.: Duke University Press.

Gunewardena, Nandini, and Mark Schuller, eds.

2008 Capitalizing on Catastrophe: Neoliberal Strategies in Disaster Reconstruction. Lanham, Md.: AltaMira.

Hardt, Michael, and Antonio Negri

2000 Empire. Cambridge, Mass.: Harvard University Press.

Harper, Ian, Nabin Rawal, and Madhusidan Subedi

2011 "Disputing Distribution: Ethics and Pharmaceutical Regulation in Nepal." Studies

Hastrup, Frida in Nepali History and Society 16, no. 1: 1-39.

2011 Weathering the World: Recovery in the Wake of the Tsunami in a Tamil Fishing Village. New York: Berghahn. 
Hoffman, Susanna M.

1999 “After Atlas Shrugs: Cultural Change or Persistence after a Disaster.” In The Angry Earth: Disaster in Anthropological Perspective, edited by Anthony Oliver-Smith and Susanna Hoffman, 302-26. New York: Routledge.

International Medical Corps (IMC)

2015 “2015 Annual Report.” Los Angeles: International Medical Corps.

James, Erica Caple

2010 Democratic Insecurities: Violence, Trauma, and Intervention in Haiti. Berkeley: University of California Press.

Klein, Naomi

2007 The Shock Doctrine: The Rise of Disaster Capitalism. New York: Picador.

Kohrt, Brandon A., and Ian Harper

2008 "Navigating Diagnoses: Understanding Mind-Body Relations, Mental Health, and Stigma in Nepal." Culture, Medicine, and Psychiatry 32: 462-91. https://doi.

Kreps, Gary A. org/10.1007/s11013-008-9110-6.

1995 "Disaster as Systemic Event and Social Catalyst: A Clarification of Subject Matter." International Journal of Mass Emergencies and Disasters 13, no. 3: 255-84.

Kunreuther, Laura

2014 Voicing Subjects: Public Intimacy and Mediation in Kathmandu. Berkeley: University of California Press.

Lassiter, Luke Eric

2005 The Chicago Guide to Collaborative Ethnography. Chicago: University of Chicago Press.

Latour, Bruno

2004 "Why Has Critique Run out of Steam? From Matters of Fact to Matters of Concern.” Critical Inquiry 30: 225-48. https://doi.org/10.1086/421123.

Liboiron, Max, Manuel Tironi, and Nerea Calvillo

2018 "Toxic Politics: Acting in a Permanently Polluted World." Social Studies of Science 48, no. 3: 331-49. https://doi.org/10.1177/0306312718783087.

Lovell, Anne M.

2011 "Debating Life after Disaster: Charity Hospital Babies and Bioscientific Futures in Post-Katrina New Orleans." Medical Anthropology Quarterly 25, no. 2: 254-77. https://doi.org/10.1111/j.1548-1387.2011.01152.x.

Luitel, Nagendra P., Mark J. D. Jordans, Anup Adhikari, Nawaraj Upadhaya, Charlotte

Hanlon, Crick Lund, and Ivan H. Komproe

2015 "Mental Health Care in Nepal: Current Situation and Challenges for Development of a District Mental Health Care Plan." Conflict and Health 9, no. 3. https://doi. org/10.1186/s13031-014-0030-5.

Nixon, Rob

2011 Slow Violence and the Environmentalism of the Poor. Cambridge, Mass.: Harvard University Press.

Nyenhuis, Michael J.

2016 “In Nepal, Mental Health Takes Center Stage." HuffPost, April 25. https://www. huffpost.com/entry/in-nepal-mental-health-ta_b_9760606.

Oliver-Smith, Anthony

1996 "Anthropological Research on Hazards and Disasters." Annual Review of Anthropology 25: 303-28. https://doi.org/10.1146/annurev.anthro.25.1.303.

Oliver-Smith, Anthony, and Susanna M. Hoffman

2002 "Introduction: Why Anthropologists Should Study Disasters." In Catastrophe and Culture: The Anthropology of Disaster, edited by Susanna M. Hoffman and Anthony Oliver-Smith, 3-22. Santa Fe, N.Mex.: School of American Research Press.

Ortner, Sherry B.

2016 "Dark Anthropology and Its Others: Theory since the Eighties." HAU 6, no. 1: 47-73. http://dx.doi.org/10.14318/hau6.1.004. 
Pandolfi, Mariella

2010 "From Paradox to Paradigm: The Permanent State of Emergency in the Balkans." In Contemporary States of Emergency: The Politics of Military and Humanitarian Interventions, edited by Didier Fassin and Mariella Pandolfi, 153-72. New York: Zone.

Pattisson, Pete

2013 “Revealed: Qatar's World Cup 'Slaves.” Guardian (UK), September 25. http:// Petryna, Adriana www.theguardian.com/world/2013/sep/25/revealed-qatars-world-cup-slaves.

2002 Life Exposed: Biological Citizens after Chernobyl. Princeton, N.J.: Princeton University Press.

Povinelli, Elizabeth A.

2011 Economies of Abandonment: Social Belonging and Endurance in Late Liberalism. Durham, N.C.: Duke University Press.

Raschig, Megan

2017 "Triggering Change: Police Homicides, Community Healing, and the Emergent Eventfulness of the New Civil Rights." Cultural Anthropology 32, no. 3: 399-423. https://doi.org/10.14506/ca32.3.07.

Redfield, Peter

2005 "Doctors, Borders, and Life in Crisis." Cultural Anthropology 20, no. 3: 328-61. https://doi.org/10.1525/can.2005.20.3.328.

Roitman, Janet

2013 Anti-Crisis. Durham, N.J.: Duke University Press.

Ruszczyk, Hanna A.

2018 "The Earthquake and Ideas Lying Around.” In Evolving Narratives of Hazard and Risk: The Gorkha Earthquake, Nepal 2015, edited by Louise Bracken, Hanna A. Ruszczyk, and Tom Robinson, 125-39. Cham, Switzerland: Palgrave Macmillan.

Seale-Feldman, Aidan

2019 "Relational Affliction: Reconceptualizing 'Mass Hysteria.” Ethos 47, no. 3: 30725. https://doi.org/10.1111/etho.12245.

2020 "Historicizing the Emergence of Global Mental Health in Nepal (1950-2019)." HIMALAYA 39, no. 2: 29-43. https://digitalcommons.macalester.edu/himalaya/ vol39/iss $2 / 7$.

Seale-Feldman, Aidan, and Nawaraj Upadhaya

2015 "Mental Health after the Earthquake: Building Nepal's Mental Health System in Times of Emergency." Hot Spots, Fieldsights, October 14. https://culanth.org/ fieldsights/mental-health-after-the-earthquake-building-nepals-mental-health-

Simpson, Edward system-in-times-of-emergency.

2014 The Political Biography of an Earthquake: Aftermath and Amnesia in Gujarat, India. Oxford: Oxford University Press.

Solnit, Rebecca

2009 A Paradise Built in Hell: The Extraordinary Communities that Arise in Disaster. New York: Penguin.

Stockton, Nick

2015 “Let's Stop Nepal's Mental Health Crisis before It Happens." Wired, May 15. https:// Ticktin, Miriam www.wired.com/2015/05/lets-stop-nepals-mental-health-crisis-happens/.

2011 Casualties of Care: Immigration and the Politics of Humanitarianism in France. Berkeley: University of California Press.

2014 “Transnational Humanitarianism.” Annual Review of Anthropology 43: 273-89.

Tironi, Manuel https://doi.org/10.1146/annurev-anthro-102313-030403.

2014 "Atmospheres of Indagation: Disasters and the Politics of Excessiveness." Sociological Review 62, supp. 1: 114-34. https://doi.org/10.1111/1467-954X.12126. 
Turner, Ralph Lilley

1965 A Comparative and Etymological Dictionary of the Nepali Language. London: Routledge and Kegan Paul.

United Nations Children's Fund

2016 "Child Protection Sub Cluster 5W Update." https://www.humanitarianresponse.

Whiting, Alex info/en/operations/nepal/document/5w-update-6-sep-0.

2016 "Mental Health Care in Emergencies 'Not an Optional Luxury': Experts." Thomson Reuters Foundation News, April 13. http://news.trust.org/item/20160413115936-

Willen, Sarah S. gz30w/.

2007 “Toward a Critical Phenomenology of 'Illegality': State Power, Criminalization, and Abjectivity among Undocumented Migrant Workers in Tel Aviv, Israel." International Migration 45, no. 3: 8-38. https://doi.org/10.1111/j.1468-2435.2007. 00409.x.

World Bank

n.d. "Personal Remittances, Received (\% of GDP)." DataBank World Development Indicators. Accessed March 8, 2020. https://data.worldbank.org/indicator/ BX.TRF.PWKR.DT.GD.ZS?most_recent_value_desc=true.

World Bank Group and World Health Organization (WHO)

2016 "Out of the Shadows: Making Mental Health a Global Development Priority." Report of proceedings of event, April 13-14. Washington, D.C.: World Bank Group and World Health Organization.

World Health Organization (WHO)

2013 "Building Back Better: Sustainable Mental Health Care after Emergencies." Geneva: WHO. http://www.who.int/mental_health/emergencies/building_ back_better/en/.

Zigon, Jarrett

2018 Disappointment: Toward a Critical Hermeneutics of Worldbuilding. New York: Fordham University Press.

2019 A War on People: Drug User Politics and a New Ethics of Community. Berkeley: University of California Press. 